\title{
Intracellular amino acid concentrations in children with chronic renal insufficiency
}

\author{
Joana E. Kist-van Holthe tot Echten ${ }^{1}$, Jan G. M. Huijmans ${ }^{2}$, Wim C. J. Hop ${ }^{3}$, Leo A. H. Monnens, \\ Maria C. J. W. de Jong ${ }^{4}$, Cornelia M. Noordzij ${ }^{1}$, Rembert Slotema ${ }^{2}$, Jeroen Nauta ${ }^{1}$, and Eric D. Wolff ${ }^{1}$ \\ 1 Department of Pediatrics, Subdivision of Nephrology, Sophia Children's Hospital/University Hospital Rotterdam, Rotterdam, The Netherlands \\ ${ }^{2}$ Departmant of Pediatrics, Subdivision of Genetic and Inborn Diseases, Sophia Children's Hospital/University Hospital Rotterdam, Rotterdam, \\ The Netherlands \\ ${ }^{3}$ Department of Epidemiology and Biostatistics, Erasmus University Rotterdam, Rotterdam, The Netherlands \\ ${ }_{4}^{4}$ Department of Pediatrics, Subdivision of Nephrology, University Hospital Nijmegen, Nijmegen, The Netherlands
}

Received January 19, 1995; received in revised form and accepted June 12, 1995

\begin{abstract}
We studied amino acid concentrations in granulocytes and plasma of 24 children with chronic renal failure and 15 healthy children. Granulocytes were isolated from $10 \mathrm{ml}$ of blood using a dextran-Ficoll-Hypaque procedure. Intracellular levels of leucine, isoleucine, methionine, phenylalanine, lysine, histidine, tyrosine, and arginine were significantly lower in children with chronic renal failure than healthy children. There were no significant differences in intracellular and plasma amino acid concentrations between children with chronic renal failure on a well-balanced protein-restricted diet and children with chronic renal failure with a normal protein intake.
\end{abstract}

Key words: Chronic renal failure - Granulocytes - Amino acids - Protein restriction

\section{Introduction}

It is well known that children and adults with chronic renal failure may have abnormal plasma and intracellular amino acid levels [1-11]. The observed abnormalities are presumably due to altered amino acid metabolism and malnutrition. Cellular malnutrition in children with chronic renal failure may contribute to their poor growth. In the present study we investigated 24 children with chronic renal failure in a prospective randomized trial and evaluated the effect of a protein-restricted diet on plasma and granulocyte free amino acids in relation to renal function and growth [12].
Table 1. Characteristics of the patients with chronic renal failure at the time of blood sampling for measurement of amino acid levels in granulocytes and plasmaa

\begin{tabular}{lll}
\hline Characteristics of the patients & $\begin{array}{l}\text { Protein- } \\
\text { restricted dict }\end{array}$ & Unrestricted diet \\
\hline No. of patients & 10 & 14 \\
Age (years) & $12.7(5.2)$ & $10.5(4.1)$ \\
Gender (M, F) & $7 / 3$ & $10 / 4$ \\
Diagnosisb, c, d & $2 / 7 / 1$ & $0 / 10 / 4$ \\
Weight for height (\%) & $108(25)$ & $100(14)$ \\
Height standard deviation & $-1.58(1.1)$ & $-1.12(1.1)$ \\
Calculated creatinine clearance & $37.3(15.9)$ & $36.1(14.2)$ \\
(ml/min per $1.72 \mathrm{~m}^{2}$ ) & &
\end{tabular}

a Data given are numbers of patients or means (standard deviation)

b Glomerulopathy

c Obstructive uropathy and/or renal dysplasia

d Miscellaneous

e Computed as $40 \times$ length $(\mathrm{cm}) /$ creatinine $(\mu \mathrm{mol} / \mathrm{l})$

\section{Patients and methods}

Twenty-four uremic children (17 boys, 7 girls with a mean age of $11.4 \pm 4.7$ years) were studied. The glomerular filtration rate varied from 15 to $78 \mathrm{ml} / \mathrm{min}$ per $1.73 \mathrm{~m}^{2}$. Fifteen healthy children ( 8 boys, 7 girls with a mean age of $9 \pm 3$ years) served as controls. All patients were in a stable condition without concurrent illnesses. Table 1 shows the characteristics of the patients with chronic renal failure.

The children in the protein-restricted group were advised to reduce their protein intake to safe levels between 0.8 and $1.1 \mathrm{~g} / \mathrm{kg}$ per day [13]. The children in the group with no dietary restriction were advised to eat at least 1.5-2.0 times the safe levels of protein, corresponding to normal protein intakes for healthy children [14]. For all children the target caloric intake was at least $100 \%$ of the energy requirement [13]. The children and their parents were asked to provide a prospective dietary diary which covered 2 days during the week and 1 day of the weekend prior to blood sampling. A specially assigned dietician supervised the dietatry diary. Protein and caloric intakes were calculated using the Dutch Nutrition Index [15]. The essential amino acid intake was calculated from the nutrition tables of Souci-FachmannKraut [16] and compared with the minimal daily requirements of amino acids for children [13]. The patients were started on sodium bicarbonate if the serum bicarbonate dropped below $21 \mathrm{mmol} / \mathrm{l}$. 


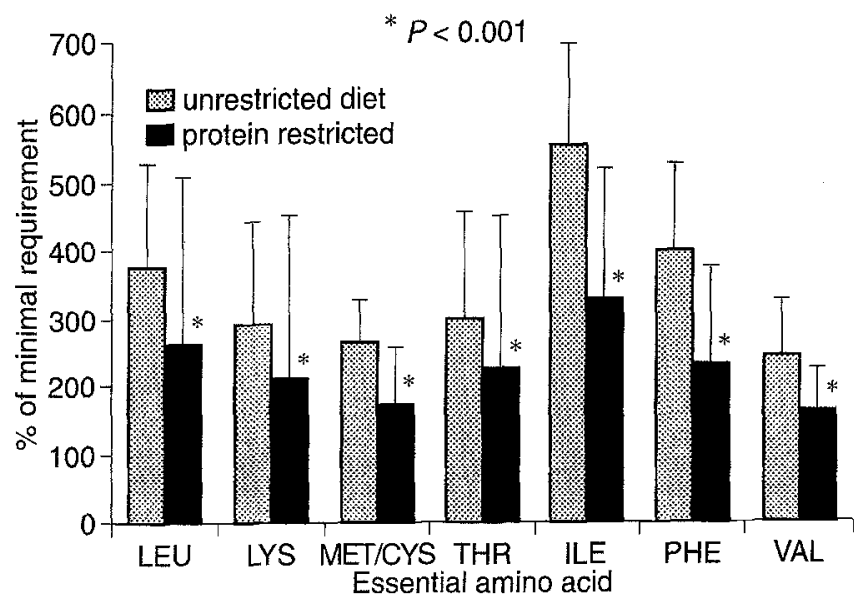

Fig. 1. Mean intake of essential amino acids of the protein-restricted and the control group, as a percentage of the minimal daily requirement [13]. ${ }^{*} P<0.001 ; L E U$, leucine; LYS, lysine, MET/CYS, methionine/cystine; THR, threonine; $I L E$, isoleucine; $P H E$, phenylalanine; $V A L$, valine

After 18-39 (mean 36.3) months on the protein-restricted diet or the diet with no restrictions. blood was drawn for granulocyte isolation and amino acid analysis after an overnight fast. Granulocytes were isolated using a dextran-Ficoll-Hypaque sedimentation procedure, as described by Metcoff et al. [11]. The leukocyte suspensions contained $83 \%-100 \%$ granulocytes (mean 96\%). The viability of the granulocytes, measured by the trypan blue exclusion test, ranged from $86 \%$ to 99\% (mean 94\%). Amino acid contents were measured by liquid column chromatography on a LKB $\alpha+$ (Pharmacia, Sweden) amino acid analyzer. Granulocyte amino acids are expressed as micromoles per gram of protein, using albumin as a standard (Lowry method), as the protein content of cells in children with chronic renal failure on a well-balanced diet does not differ from healthy children [10, 17]. Plasma amino acid concentrations are expressed as micromoles per milliliter, given as the medians and their range.

Weight, height, upper arm circumference, and triceps skinfold thickness of the children were measured by the same observer 6 months prior to and on the day of sampling. Weight is expressed as weight for height percentile and height as height standard deviation score for healthy Dutch children [18].

Statistics. Differences in the estimated intake of essential amino acids and the arnino acid concentrations in granulocytes and plasma were eyaluated by the Mann-Whitney test. The correlations between amino acid concentrations and protein intake, glomerular filtration rate, and anthropometric measures were computed using regression analysis after logarithmic transformation of amino acid levels (or the level +1 in the case of occasional values of zero), due to their skew distribution. The limit of significance was taken as $5 \%$.

\section{Results}

The mean (SD) estimated protein intake differed significantly between the protein-restricted group $[1.1(0.4) \mathrm{g} / \mathrm{kg}$ per day (113\% of safe level)] and the group without dietary restrictions [2.0 (0.6) $\mathrm{g} / \mathrm{kg}$ per day (205\% of safe level)]. Energy intakes of both groups were adequate: $91 \%$ and $110 \%$ of the energy requirement for the protein-restricted group and the group with no dietary restriction, respectively $(P<0.05)$. The estimated amino acid and essential amino acid intakes in the protein-restricted group were well above $100 \%$ of minimal daily requirements, valine being

Table 2. Amino acid concentrations in granulocytes $(\mu \mathrm{mol} / \mathrm{g}$ protein) for the protein-restricted group, the group with no dietary restriction, and healthy children

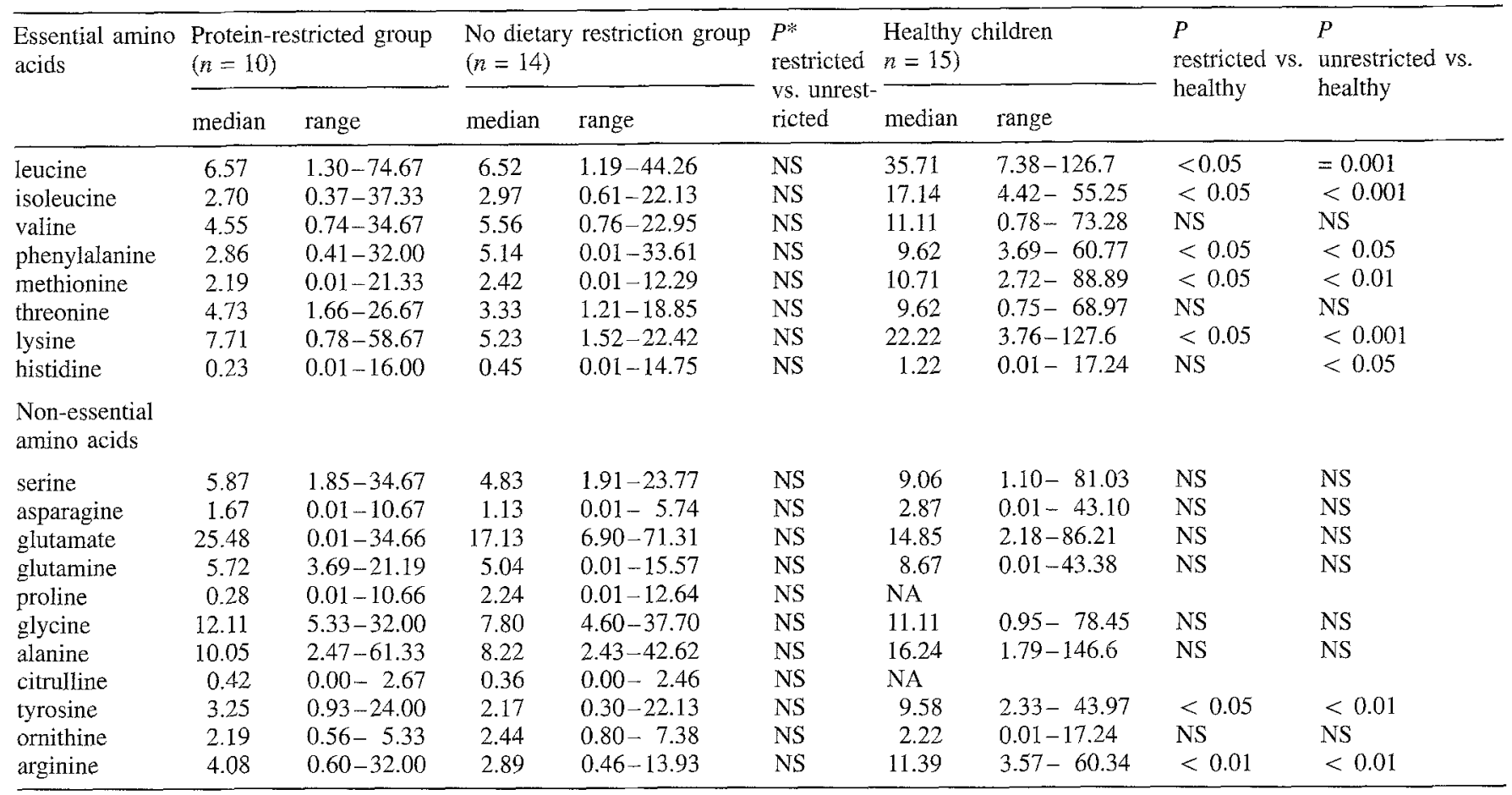

NA. Not available

* $P$ values are given if there is a significant difference between the median amino acid level in the granulocytes of the children with the proteinrestricted diet and the diet without restrictions, and of each group compared with healthy children 
Table 3. Amino acid concentrations in plasma $(\mu \mathrm{mol} / \mathrm{ml})$ of the children in the protein-restricted group, the group with no dietary restriction, and healthy children

\begin{tabular}{|c|c|c|c|c|c|c|c|c|c|}
\hline \multirow[t]{2}{*}{$\begin{array}{l}\text { Essential amino } \\
\text { acids }\end{array}$} & \multicolumn{2}{|c|}{$\begin{array}{l}\text { Protein-restricted group } \\
(n=10)\end{array}$} & \multicolumn{2}{|c|}{$\begin{array}{l}\text { No dietary restriction group } \\
(n=14)\end{array}$} & \multirow{2}{*}{$\begin{array}{l}P \\
\text { restricted } \\
\text { vs. unre- } \\
\text { stricted }\end{array}$} & \multicolumn{2}{|c|}{$\begin{array}{l}\text { Healthy children } \\
(n=15)\end{array}$} & \multirow{2}{*}{$\begin{array}{l}P \\
\text { restricted vs. } \\
\text { healthy }\end{array}$} & \multirow{2}{*}{$\begin{array}{l}P \\
\text { unrestricted vs. } \\
\text { healthy }\end{array}$} \\
\hline & median & range & median & range & & median & range & & \\
\hline leucine & 0.09 & $0.07-0.15$ & 0.09 & $0.05-0.25$ & NS & 0.09 & $0.06-0.12$ & NS & NS \\
\hline isoleucine & 0.05 & $0.04-0.10$ & 0.05 & $0.03-0.11$ & NS & 0.05 & $0.03-0.06$ & NS & NS \\
\hline valine & 0.17 & $0.12-0.23$ & 0.16 & $0.09-0.33$ & NS & 0.20 & $0.14-0.26$ & NS & NS \\
\hline phenylalanine & 0.05 & $0.04-0.09$ & 0.05 & $0.03-0.09$ & NS & 0.05 & $0.03-0.07$ & NS & NS \\
\hline methionine & 0.02 & $0.01-0.03$ & 0.02 & $0.01-0.05$ & NS & 0.02 & $0.01-0.03$ & NS & NS \\
\hline threonine & 0.10 & $0.06-0.13$ & 0.09 & $0.06-0.20$ & NS & 0.10 & $0.07-0.15$ & NS & NS \\
\hline lysine & 0.13 & $0.10-0.16$ & 0.13 & $0.10-0.27$ & NS & 0.14 & $0.09-0.15$ & NS & NS \\
\hline histidine & 0.06 & $0.05-0.09$ & 0.07 & $0.04-0.10$ & NS & 0.06 & $0.04-0.13$ & NS & NS \\
\hline \multicolumn{10}{|l|}{$\begin{array}{l}\text { Non-essential } \\
\text { amino acids }\end{array}$} \\
\hline serine & 0.09 & $0.07-0.17$ & 0.08 & $0.02-0.14$ & NS & 0.12 & $0.08-0.19$ & $<0.05$ & $<0.001$ \\
\hline asparagine & 0.07 & $0.05-0.09$ & 0.06 & $0.04-0.13$ & NS & 0.08 & $0.05-0.11$ & $<0.05$ & NS \\
\hline glutamate & 0.07 & $0.02-0.19$ & 0.06 & $0.02-0.18$ & NS & 0.06 & $0.01-0.17$ & NS & NS \\
\hline glutamine & 0.52 & $0.30-0.66$ & 0.49 & $0.24-0.66$ & NS & 0.53 & $0.30-0.58$ & NS & NS \\
\hline proline & 0.25 & $0.20-0.52$ & 0.28 & $0.12-0.51$ & NS & $\mathrm{NA}$ & & & \\
\hline glycine & 0.32 & $0.17-0.69$ & 0.27 & $0.16-0.38$ & $<0.05$ & 0.24 & $0.14-0.43$ & $<0.01$ & NS \\
\hline alanine & 0.33 & $0.17-0.82$ & 0.31 & $0.18-0.53$ & NS & 0.28 & $0.18-0.56$ & NS & NS \\
\hline citrulline & 0.06 & $0.04-0.10$ & 0.06 & $0.02-0.10$ & NS & 0.03 & $0.00-0.04$ & $<0.001$ & $<0.001$ \\
\hline tyrosine & 0.04 & $0.03-0.09$ & 0.05 & $0.03-0.13$ & NS & 0.06 & $0.04-0.08$ & NS & NS \\
\hline ornithine & 0.05 & $0.04-0.10$ & 0.05 & $0.03-0.07$ & NS & 0.06 & $0.03-0.15$ & NS & NS \\
\hline arginine & 0.07 & $0.07-0.10$ & 0.08 & $0.03-0.12$ & NS & 0.06 & $0.02-0.10$ & NS & $<0.05$ \\
\hline
\end{tabular}

Table 4. Correlations between amino acids in granulocytes and in plasma and the change $(\triangle)$ in weight for height, $\triangle$ height standard deviation score (SDS), $\triangle$ upper arm circumference, and $\triangle$ triceps skinfold thickness of the children with chronic renal failurea

\begin{tabular}{|c|c|c|c|c|c|c|}
\hline \multirow[t]{2}{*}{ Parameter } & \multicolumn{3}{|l|}{ Granulocyte } & \multicolumn{3}{|l|}{ Plasma } \\
\hline & amino acid & $P$ & $r$ & amino acid & $P$ & $r$ \\
\hline$\triangle$ Weight for height & $\begin{array}{l}\text { leucine } \\
\text { isoleucine } \\
\text { valine } \\
\text { methionine } \\
\text { lysine } \\
\text { ornithine } \\
\text { arginine }\end{array}$ & $\begin{array}{l}<0.05 \\
<0.05 \\
<0.01 \\
<0.05 \\
<0.05 \\
<0.05 \\
<0.05\end{array}$ & $\begin{array}{l}0.48 \\
0.48 \\
0.55 \\
0.47 \\
0.47 \\
0.48 \\
0.44\end{array}$ & $\begin{array}{l}\text { phenylalanine } \\
\text { proline } \\
\text { glycine } \\
\text { alanine } \\
\text { ornithine }\end{array}$ & $\begin{array}{l}<0.01 \\
<0.05 \\
<0.05 \\
<0.05 \\
<0.05\end{array}$ & $\begin{array}{l}-0.57 \\
-0.59 \\
-0.47 \\
-0.50 \\
-0.45\end{array}$ \\
\hline$\triangle$ Height SDS & & & & $\begin{array}{l}\text { glutamate } \\
\text { glutamine } \\
\text { citrulline } \\
\text { arginine }\end{array}$ & $\begin{array}{l}<0.001 \\
<0.05 \\
<0.01 \\
<0.05\end{array}$ & $\begin{array}{r}0.66 \\
-0.52 \\
-0.55 \\
-0.48\end{array}$ \\
\hline$\triangle$ Upper arm circumference & & & & $\begin{array}{l}\text { phenylalanine } \\
\text { ornithine }\end{array}$ & $\begin{array}{l}<0.05 \\
<0.05\end{array}$ & $\begin{array}{l}-0.43 \\
-0.51\end{array}$ \\
\hline$\triangle$ Triceps skinfold thickness & $\begin{array}{l}\text { histidine } \\
\text { asparagine } \\
\text { glycine } \\
\text { citrulline }\end{array}$ & $\begin{array}{l}<0.05 \\
<0.05 \\
<0.05 \\
<0.05\end{array}$ & $\begin{array}{l}-0.45 \\
-0.45 \\
-0.50 \\
-0.52\end{array}$ & & & \\
\hline
\end{tabular}

a Of 19 amino acids measured in each group only significant correlations are presented

the limiting essential amino acid (Fig. 1). There was no significant correlation between the intake of any of the essential amino acids and the amino acid concentrations in the granulocytes or in plasma.

Plasma and granulocyte amino acid concentrations are shown in Tables 2 and 3 . We found a wide range of amino acid levels in the granulocytes of children with chronic renal failure as well as in healthy children. There were no significant differences between the protein-restricted group and the group without dietary restriction. Four amino acids in granulocytes revealed a negative correlation with the corresponding amino acid in plasma (phenylalanine, asparagine, glycine, and ornithine). The glomerular filtration rate correlated with plasma valine $(r=0.52, P=0.01)$ and arginine $(r=0.41, P<0.05)$ concentrations. Seven amino acids in granulocytes and five amino acids in plasma cor- 
related with the change $(\triangle)$ in weight for height, while four plasma amino acids exhibited a correlation with $\triangle$ height standard deviation score (Table 4). Mean plasma bicarbonate levels in the protein-restricted group and the group with no dietary restriction were $25.6 \mathrm{mmol} / \mathrm{l}$ (range 22.1-34.4 $\mathrm{mmol} / \mathrm{l}$ ) and $25.3 \mathrm{mmol} / \mathrm{l}$ (range 21.4-28.6 $\mathrm{mmol} / \mathrm{l})$ respectively $(P=\mathrm{NS})$.

\section{Discussion}

There are firm indications that plasma amino acids are of limited value for assessing the total pool of amino acids, as they are known to mirror recent exogenous intake, as well as uptake, synthesis, and export by cells $[4,7]$. Granulocytes are interesting because the relatively short halflife and rapid turnover (from differentiation in the bone marrow, through extrusion into the blood, and survival in the circulation of about 7 days) implies that their metabolic activities, e.g., protein synthesis or energy production, reflect the availability of nutrient substrates in their microenvironment. Furthermore, the impaired host immunity associated with uremia is mainly caused by functional and metabolic disturbances of the granulocytes [19].

Unlike a muscle biopsy, isolation of granulocytes is noninvasive and therefore a valuable method for measuing intracellular levels of amino acids. Published values of amino acid levels in granulocytes in children with renal failure are scarce and originate from only 10 patients on hemodialysis and 8 on continuous ambulatory peritoneal dialysis (CAPD) [8, 9]. There are no data on patients with chronic renal failure. Although exact comparison of results is not possible due to different laboratory techniques and ways of expressing the data, the trend is the same: most essential amino acids in the granulocytes (leucine, isoleucine, valine, phenylalanine, methionine, lysine) are significantly lower than in healthy subjects.

Amino acid levels in muscle cells of children with chronic renal failure are expressed per $100 \mathrm{~g}$ wet tissue or per liter intracellular water, which also makes comparison difficult $[2,5,10]$. Broyer et al. [5] found decreased levels in muscle cells of valine and alanine and increased levels of glutamine in 20 children with chronic renal failure compared with healthy children. Delaporte et al. [2] found that muscle pools of essential and non-essential amino acids were increased in eight children with chronic renal failure. Canepa et al. [10] found lower levels of valine and isoleucine in muscle cells of 15 children with end-stage renal disease compared with healthy children; these results are comparable to our findings in granulocytes. The cause of the low intracellular branched-chain amino acids (leucine, isoleucine, and valine) in uremia is still unclear. These amino acids are mainly metabolized in muscle by deamination to their ketoanalogues. This is followed by oxidation, which is mediated via a common branched-chain keto acid dehydrogenase complex, which is rate limiting for branched-chain amino acid degradation. In normal and uremic rats, acidosis appears to enhance protein degradation in muscle, an effect which is thought to be due to stimulation of branched-chain amino acid decarboxylation and thereby to cause depletion of the branched-chain amino acids $[20,21]$. The children in our study with chronic renal failure had no metabolic acidosis.

Some of the plasma and intracellular amino acid abnormalities in uremia are similar to those in malnutrition, and it has been suggested that they are in part attributable to dietary inadequacy [7]. The children in our study were not malnourished; this is confirmed by the adequate energy intake and a mean weight for height of $102 \%$. Although the protein-restricted group in our study consumed significantly fewer essential amino acids than the group with no dietary restriction, the mean intake of each essential amino acid was well above the minimal daily requirement.

Our study indicates that there is no important difference in intracellular and plasma amino acids between children on a well-balanced protein-restricted diet and children with a normal protein intake. Supplementation of this proteinrestricted diet $(0.8-1.1 \mathrm{~g} / \mathrm{kg}$ per day) with essential amino acids can therefore not be supported by this study.

The median levels of 8 of the amino acids isolated from granulocytes were found to be significantly lower in the children with chronic renal failure than in healthy children. This might suggest cellular malnutrition in children with chronic renal failure.

We found significant correlations between the change in weight for height in the preceding 6 months and 7 of 19 intracellular amino acids and 5 plasma amino acids. There was a positive correlation for intracellular amino acids and a negative correlation for plasma amino acids, suggesting that relatively high intracellular amino acid levels and relatively low extracellular levels may contribute to better growth of these children.

The reason for the low intracellular amino acid concentrations in granulocytes from patients with renal failure is uncertain. Similar results were reported by Metcoff et al. [7] in children on CAPD. Reduced protein synthesis was demonstrated in the granulocytes of these children. An altered transport of amino acids into the granulocytes and intracellular metabolism of these amino acids in the granulocytes, resulting in an abnormal pattern of intracellular protein, could both contribute to the lowered intracellular amino acid concentration. These hypotheses require further study.

Acknowledgements. The study was supported by the Dutch Kidney Foundation, grant no. C 87.648 and by the Nutricia Research Foundation. The study is also part of the "European Study for Nutritional Treatment of Chronic Renal Failure in Childhood", BMFT-grant no. 07047420, (coordinator Prof. Dr. O. Mehls). Eric van der Meyden and Robin Jankie are gratefully acknowledged for their technical assistance.

\section{References}

1. Counahan R, El-Bishti M, Cox, BD, Ogg CS, Chantler C (1976) Plasma amino acids in children and adolescents on haemodialysis. Kidney Int 10: 471-477

2. Delaporte C, Jean G, Broyer M (1978) Free plasma and muscle amino acids in uremic children. Am J Clin Nutr 31: 1647-1651

3. Fürst P, Ahlberg A, Alvestrand A, Bergström J (1978) Principles of essential amino acid therapy in uraemia. Am J Clin Nutr 31: $1744-1755$ 
4. Fürst $P$ (1989) Amino acid metabolism in uremia. J Am Coll Nutr 8: $310-323$

5. Broyer M, Jean G, Dartois A-M, Kleinknecht C (1980) Plasma and muscle free amino acids in children at the early stages of renal failure. Am J Clin Nutr 33: 1396-1401

6. Jones R, Dalton N, Turner C, Start K, Haycock G, Chantler C (1983) Oral essential amino acid and ketoacid supplements in children with chronic renal failure. Kidney Int 24: 95-103

7. Metcoff J, Fürst P, Schärer K, Distler G, Weber R, Mangold J, Graser T, Pfaff G, Schonberg D (1989) Energy production, intracellular amino acid pools and protein synthesis in chronic renal failure. J Am Coll Nutr 8: 271-284

8. Canepa A, Perfumo F, Carrea A, Sanguineti A, Piccardo MT, Gusmano R (1989) Measurement of free aminoacids in polymorphonuclear leucocytes by high-performance liquid chromatography. J Chromatogr 491: 200-208

9. Canepa A, Perfumo F, Carrea A, Giallongo F, Verrina E, Cantaluppi A, Gusmano R (1991) Long-term effect of amino-acid dialysis solution in children on continuous ambulatory peritoneal dialysis. Pediatr Nephrol 5: 215-219

10. Canepa A, Divino Filho JC, Forsberg A-M, Perfumo F, Carrea A, Gusmano R, Bergström I (1992) Nutritional status and muscle amino acids in children with endstage renal failure. Kidney Int 41 : 1016-1022

11. Metcoff J, Dutta S, Burns G, Pederson J, Matter B, Rennert O (1983) Effects of aminoacid infusions on cell metabolism in haemodialyzed patients with uraemia. Kidney Int 24 [Suppl 16]: 87-92

12. Kist-van Holthe tot Echten JE, Nauta J, Hop WCJ, Reitsma-Bierens WCC, Ploos van Amstel SLB, Acker KJ van, Noordzij CM,
Wolff ED (1993) Protein restriction in chronic renal failure. Arch Dis Child 68: $371-375$

13. World Health Organization (1985) Energy and protein requirements. Report of a joint WHO/FAO/UNU expert consultation. Technical report series, no 724. WHO, Geneva, pp 65, 95, 98, 105, 106

14. Ministries of Health and Agriculture (1988) What is eaten in The Netherlands Results of the dietary assessment 1987-1988. Ministries of Health and Agriculture Rijswijk, The Netherlands

15. CIVO-Instituten TNO (1987) Dutch Nutrition Index 1986-1987. Stichting NEVO, voorlichtings bureau voor de voeding. Zeist, The Netherlands,

16. Souci-Fachmann-Kraut (1986) Food composition and nutrition tables 1986-1987. Wissenschaftliche Verlagsgesellschaft, Stuttgart

17. Lowry OH, Rosenbrough NJ, Farr LA, Randall RJ (1951) Protein measurement with the Folin reagent. J Biol Chem 193: 265-275

18. Roede MJ, Wieringen JC van (1985) Growth diagrams 1980. Netherlands third nation-wide biometric survey. T Soc Gezondheidszorg [Suppl] 63: 1-34

19. Haag-Weber M, Hörl WH (1993) Uremia and infection: mechanisms of impaired cellular host defence. Nephron 63: 125-131

20. May RC, Kelly RA, Mitch WE (1986) Metabolic acidosis stimulates protein degradation in rat muscle by a glucocorticoid-dependent mechanism. J Clin Invest 77: 614-621

21. May RC, Kelly RA, Mitch WE (1987) Mechanisms for defects in muscle protein metabolism in rats with chronic uremia. Influence of metabolic acidosis. J Clin Invest 79: 1099-1103

\section{The European Society for Paediatric Nephrology will be holding its 30th Annual Meeting}

at the Centre Hospitalier Universitaire Vaudois (CHUV) in Lausanne, Switzerland, from August 29 to September 1, 1996.

The program will include:

- State of the Art Lectures

- Symposia - Free Communications - Poster Sessions

- A Round Table: Processing towards, suffering from, outliving terminal renal failure: ask the experts around the table!

\section{and a novelty}

- Controversies on practical clinical issues led by world renowned experts in the field

Deadline for abstracts: abstracts must be received by March 15, 1996.

For all inquiries contact: President of the Congress

Prof. Dr Jean-Pierre Guignard

Department of Paediatrics

CHUV

1011 Lausanne

Phone: 0041213143569

Switzerland

Fax: 0041213143626 